\title{
Penguatan Spritualitas dalam Komunitas Resimen Mahasiswa
}

\author{
Dian Yudhawati 1 \\ 1 Program Studi Psikologi Universitas Teknologi Yogyakarta \\ dianyudhawati@uty.ac.id
}

\begin{abstract}
Spirituality is important to create quality human beings and people who are able to understand the meaningful of life. The ability to understand life can make someone reach for meaning and develop it into a happiness. Building spirituality is not just doing religious rituals Efforts to build spiritual values can also be done in various activities that are able to accept diversity so as to increase insight into the meaning of life for someone. The development of spirituality can also be found in community life that has a strong sense of togetherness and kinship. Student Regiment is a community referred to in this study. The results showed that there was a strengthening of spirituality possessed by the Student Regiment members in carrying out various activities in their community.
\end{abstract}

Abstrak: Spiritualitas merupakan hal yang penting untuk menciptakan manusia yang berkualitas dan manusia yang mampu memahami kebermaknaan hidup. Kemampuan memahami kehidupan dapat membuat seseorang meraih makna dan mengembangkannya menjadi suatu kebahagiaan. Membangun spiritualitas bukanlah sekedar melakukan ritual keagamaan Upaya membangun nilai-nilai spiritual dapat dilakukan pula dalam berbagai kegiatan yang mampu menerima keberagaman sehingga dapat menambah wawasan tentang makna hidup bagi seseorang. Berkembangnya spiritualitas juga dapat ditemukan pada kehidupan komunitas yang memiliki rasa kebersamaan dan kekeluargaan yang kuat. Resimen Mahasiswa merupakan suatu komunitas yang dimaksud dalam penelitian ini. Hasil penelitian menunjukkan tentang adanya penguatan spiritualitas yang dimiliki oleh anggota Resimen Mahasiswa dalam melaksanakan berbagai kegiatan di dalam komunitasnya.

Kata kunci : Spiritualitas; Resimen Mahasiswa

\section{Pendahuluan}

Spiritualitas merupakan hal penting yang saat ini sering menjadi kajian dalam psikologi. Adanya spiritualitas, mendorong individu untuk memaknai nilai-nilai kehidupan, berkomitmen dan bertanggung jawab (Hudha, 2012). Namun hal tersebut, memerlukan media yang dapat menstimulasi individu menemui maknanya baik secara kognitif maupun afektif. Salah satunya adalah faktor lingkungan sosial yang bersedia menerima keberagaman sebagai suatu harmoni. Resimen Mahasiswa memfasilitasi adanya keberagaman tersebut dalam berbagai kegiatan yang dilakukan.

Menurut Johar (dalam Nasution, 2009) spiritualitas adalah usaha yang mendasar untuk mencari makna kehidupan ini. Spiritualitas digunakan untuk menjadi luwes, kreatif dan berwawasan luas ketika berhadapan dengan masalah eksistensial yaitu 
ketika seseorang merasa terpuruk, terjebak oleh kebiasaan, kekhawatiran dan masalah masa lalu akibat penyakit dan kesedihan. Spiritualitas membuat seseorang sadar bahwa dirinya mempunyai masalah eksistensial dan merasa mampu mengatasi persoalan -atau setidak-tidaknya bisa berdamai dengan masalah tersebut. Spiritualitas memberi rasa yang "dalam" menyangkut perjuangan hidup.

Tuntutan akan kebutuhan spiritual begitu mendesak bagi kemanusiaan universal sehingga dalam persoalan-persoalan yang paling sederhana sekalipun harus diupayakan tetap menuju pada jalur spiritualitas (Suseno, 2012).Bahkan menurut Zohar (dalam Azzet, 2013) kecerdasan spiritual dinilai sebagai kecerdasan tertinggi karena erat kaitannya dengan kesadaran seseorang untuk bisa memaknai segala sesuatu dan merupakan jalan untuk bisa merasakan sebuah kebahagiaan. Hudha (2012) menyatakan bahwa spiritual merupakan salah satu komponen yang mendukung perubahan realitas diri, seperti yang digambarkan sebagai berikut

\section{Komponen pendukung Perubahan Realitas Diri}

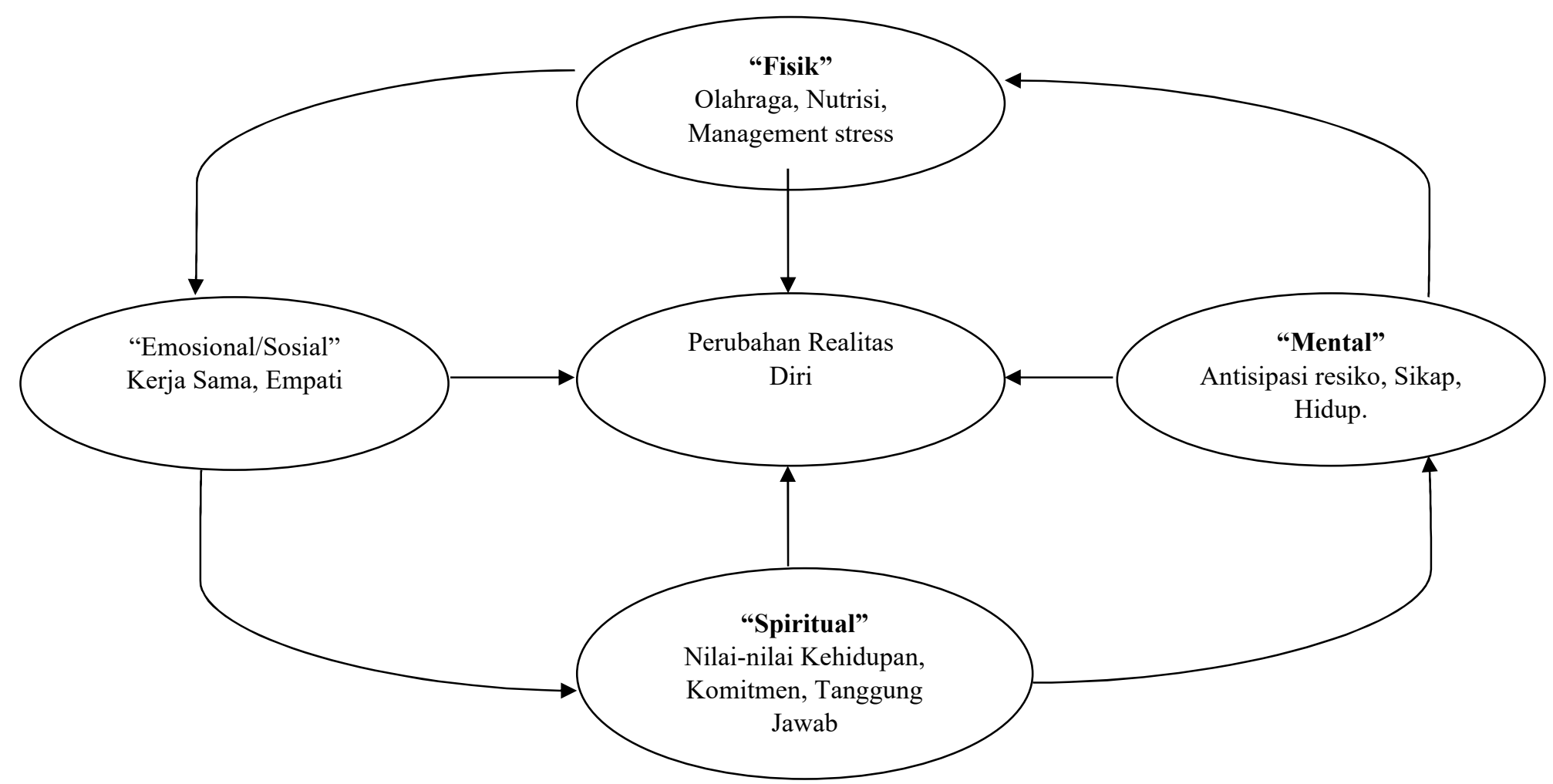




\section{WACANA}

Seseorang yang memiliki komponen spiritual dalam hidupnya, akan dapat memaknai nilai-nilai kehidupan, memiliki komitmen dan tanggung jawab dalam melakukan segala sesuatu dalam melakukan perubahan realitas diri.

Dalam membangun spiritual diri, tidak terlepas pula dari unsur fisik, mental dan hubungan social. Dengan adanya unsur fisik, mental dan hubungan social yang baik, dapat terbangun komponen spiritual yang matang pula

Pentingnya spiritualitas dalam kesehatan dapat dilihat dari definisi kesehatan menurut Organisasi Kesehatan Dunia atau World Health Organization (WHO) yang menetapkan empat unsur kesehatan yaitu sehat fisik, psikis, sosial, dan spiritual. WHO juga mendefinisikan sehat sebagai suatu keadaan sejahtera yang meliputi fisik (organobiologik), mental (psikologik), sosial, dan spiritual, yang tidak hanya bebas dari penyakit atau kecacatan. Dengan demikian dimensi spiritual merupakan salah satu unsur atau aspek yang membentuk manusia secara utuh.

Spiritualitas merupakan kepercayaan dasar akan adanya suatu kekuatan besar yang mengatur alam semesta. Spiritualitas merupakan kekuatan yang menyatukan, memberi makna pada kehidupan dan nilai-nilai individu, persepsi, kepercayaan dan keterikatan di antara individu.

Spiritualitas memiliki 4 karakteristik yang harus terpenuhi yaitu hubungan dengan diri sendiri, hubungan dengan alam, hubungan dengan orang lain, dan hubungan dengan Tuhan. Kebutuhan spiritual merupakan kebutuhan untuk mencari arti dan tujuan hidup, kebutuhan untuk mencintai dan dicintai serta rasa keterikatan, kebutuhan untuk memberikan dan mendapatkan maaf. (Frager, 2014)

Spiritulitas dapat meningkatkan kesehatan mental terhadap suatu diagnosis penyakit kronis. Kekuatan spiritual seseorang yang rendah dapat menimbulkan permasalahan psikososial di bidang kesehatan. Psychological Association menyatakan bahwa spiritualitas dapat meningkatkan kemampuan seseorang dalam mengatasi penderitaan jika seseorang sedang sakit dan mempercepat penyembuhan selain terapi medis yang diberikan. Oleh sebab itu, pada pasien kanker spiritualitas bermanfaat untuk menjaga harga diri, meningkatkan makna dan tujuan hidup, memberikan kenyamanan emosional dan memberikan harapan hidup. Dukungan spiritual juga dapat meringankan kondisi psikologis pasien seperti takut, syok, putus asa, marah, cemas, dan depresi 


\section{WACANA}

Salah satu bagian penting dari pengalaman dalam menjalankan ritualitas keagamaan bagi mereka yang percaya adalah sesuatu yang berhubungan dengan mistis yang langsung dialami oleh mereka sendiri. Orang pergi ke tempat fitness, membaca buku, datang ke kelas untuk belajar, menghadiri pesta untuk mengembangkan fisik, intelektualitas, dan kehidupan sosial. Namun mereka ke gereja dalam rangka memperkuat spiritual. Perasaan spiritual, baik itu secara fisik maupun emosional adalah sulit untuk didefinisikan karena hal tersebut bersifat universal. Beberapa orang mendapatkannya dengan cara berdoa, dan sebagian yang lainnya didapat melalui mimpi, bakti sosial, dan bersatu dengan alam.

Perasaan spiritual merupakan pengalaman yang besar yang di dalamnya berkembang hal-hal mistis, praktek peribadatan guna mencapai perasaan spiritualitas. Kaum Yahudi Chasidic melakukan Zohar, Kaum muslim melakukan gerakan tarian, Pendeta Katolik bermeditasi dan abstain terhadap seks. Pada kenyataannya bahwa pengalaman spiritualitas memberikan pemahaman yang mendalam dan dapat dinikmati oleh semua orang, bahkan mereka yang kurang religius pun mencari pengalaman spiritual melalui cara yang non-religius. Sebagai contoh beberapa orang mengkonsumsi LSD (obat terlarang), berhalusinasi dengan mengkonsumsi jamur, atau obat terlarang lainnya untuk mendapatkan pengalaman spiritual.

Spiritualitas saat ini menjadi kata yang banyak digunakan oleh orang-orang yang tidak menganut agama tertentu. Bagi dunia akademis, kaum liberal, dan generasi saat ini, ide spiritualitas, percaya pada kekuatan yang maha kuasa yang menentukan segala sesuatu telah menarik perhatian banyak orang. Apapun keyakinan orang tersebut dan dari golongan manapun mereka berasal spiritualitas merupakan komponen yang penting untuk dapat merasakan kebahagiaan. Agama berkenaan dengan praktek secara institusional dan terkait dengan doktrin, sedangkan spiritualitas selalu terkait dengan perkembangan personal dan inspirasi. George Vaillant, seorang psikiatris mengatakan bahwa yang terpenting dari spiritualitas adalah mengalami perasaan positif seperti rasa cinta, gembira, dan senang seseorang terhadap sesuatu yang lebih dari ia dibayangkan. Artinya perasaan positif membuat hubungan menjadi erat dan selalu terhubung dengan orang lain.

Ketika seseorang merasakan perasaan spiritualitas yang menghubungkannya dengan orang lain, dengan lingkungan, alam sekitar, dan bahkan dengan dunia, ini berarti orang tersebut seperti sedang melakukan hal baik, karena mereka memiliki 
penghargaan yang baik terhadap lingkungan di sekitarnya. Robert Emmons, seorang psikolog mempelajari dampak/keuntungan dari adanya perasaan gembira pada diri seseorang. Menurut hasil penelitiannya, ketika seseorang merasakan kebahagiaan, mereka tidak saja memperhatikan hal positif tentang kehidupannya sendiri, tetapi juga memperhatikan bagaimana orang lain membantu mereka dan rasa senang itu membuat mereka ingin melakukan hal yang sama baiknya dan membantu orang lain. Sehingga tidak mengherankan hasil penelitian Emmon menunjukkan bahwa responden mengalami perasaan gembira cenderung lebih bahagia.

Agama Budha adalah satu agama yang terbuka terhadap usaha memperoleh kebahagiaan dan menganjurkan kita untuk memiliki perasaan positif. Integral berarti memahami, mengetahui dan menjaga perasaan positif yang diajarkan dalam agama Budha. Tokohnya yang terkenal adalah Dalai Lama pernah mengundang Richard Davidson, seorang tokoh neorosaintis ternama dari Universitas Wisconsin ke Dharmasala, India guna mewawancarai biarawan menegenai perasaan/emosi mereka dan pengalaman spiritual mereka. Davidson bercerita kepada para sahabat dan kolega kampusnya tentang pengalaman batinnya yang tenang setelah bertemu dengan Dalai Lama.

Davidson dan koleganya menguji kekuatan meditasi secara ilmiah. Dalam satu penelitian, mereka menempelkan suatu alat di atas kepala Mathieu, biarawan yang bekelahiran Perancis dan mengamatinya. Richard telah menjalani kehidupan spiritual lebih dari sepuluh ribu jam bermeditasi dan menyendiri selama bertahun-tahun. Pada permulaan test, Davidson dan koleganya meminta Richard untuk relax, dan merekam kegiatan elektrik otaknya. Proses aktivasi otak begitu dirasakan oleh peneliti dan seakan-akan alat tidak berfungsi dengan baik. Kemudian mereka mencoba lagi proses yang sama dengan mengambil sampel dari biarawan lain, dan siswa lokal sebagai kelompok kontrol. Dalam percobaan kedua, terdapat gelombang positif dalam otak biarawan sebanyak tiga puluh tiga kali sama kuatnya dengan gelombang positif yang ada pada mahasiswa, namun otak biarawan terlihat lebih banyak yang aktif. Khususnya otak biarawan bagian kiri depan nampak lebih aktif. Area otak yang diteliti ini memiliki hubungan erat dengan perasaan positif yang dimiliki oleh responden.

Nampak bahwa perasaan positif dan pengalaman spiritual yang dialami dalam kehidupan di dunia ini adalah saling terkait satu sama lain. Pada saat orang menghadiri kebaktian di gereja, menyanyikan hymne, berdoa, dan terlibat dalam kegiatan keagaam 
yang lain mereka merasakan perasaan yang positif. Pengalaman spiritualitas dapat berupa luapan emosi yang terpisah dari perasaan akan keberadaan tuhan. (Diener, 2008)

Dengan demikian maka dapat di paparkan bahwa makna dari spiritualitas ialah merupakan sebagai pengalaman manusia secara umum dari suatu pengertian akan makna, tujuan dan moralitas. Spiritualitas atau jiwa sebagaimana yang telah digambarkan oleh tokoh -tokoh sufi adalah suatu alam yang tak terukur besarnya, ia adalah keseluruhan alam semesta, karena ia adalah salinan dariNya segala hal yang ada di dalam alam semesta terjumpai di dalam jiwa, hal yang sama segala apa yang terdapat di dalam jiwa ada di alam semesta, oleh sebab inilah, maka ia yang telah menguasai alam semesta, sebagaimana juga ia yang telah diperintah oleh jiwanya pasti diperintah oleh seluruh alam semesta (Anwar dan Solihin, 2000)

Jika dalam agama Budha, hidup adalah untuk menderita, namun dalam pandangan Islam hidup adalah sebagai perjuangan, bekerja keras untuk terlibat jihad setiap saat dan dalam berbagai tingkat. Model analisis klasik tentang jiwa manusia meletakkan "hati" manusia sebagai pusat perjuangan, yakni tarik menarik yang ketat antara "spirit" (kebaikan) dan "ego" (kejahatan). Kebutuhan manusia akan Tuhan-nya merupakan fitrah yang tidak bisa dinisbatkan manusia. Jika manusia menisbatkan fitrahnya itu berarti manusia tersebut telah memarjinalkan potensi beragamanya atau spiritualnya. Seperti halnya firman Allah SWT dalam surat ar-Ruum ayat 30 ;

Artinya : "Maka, hadapkanlah wajahmu dengan lurus kepada agama (Allah SWT)., (tetaplah atas) fitrah Allah SWT., yang telah menciptakan manusia menurut fitrah itu. Tidak ada perubahan pada fitrah Allah SWT., itulah agama yang lurus ; tetapi kebanyakan manusia tidak mengetahuinya”. (Q.S. ar-Ruum : 30).

Jiwa atau ruh merupakan hakikat pada diri manusia yang abadi, yang perenial, dan tidak akan berubah sepanjang masa, yaitu fitrahnya, yang membuat selamanya merindukan kebenaran, dengan puncaknya ialah kerinduan kepada Tuhan. Seperti yang telah digambarkan dalam al Qur'an surat al-Fajr ayat 27-30. Artinya : "Hai jiwa yang tenang ! kembalilah kepada Tuhanmu dengan hati yang puas lagi diridhai-Nya. Kemudian, masuklah ke dalam kelompok hamba-hamba-Ku, dan masuklah ke dalam surga-Ku". (Q.S. al-Fajr: ayat 27-30).

Menurut Shafwan (2000) ada macam-macam spiritualitas yaitu, spiritualitas Islam dan spiritualitas kajian barat dan timur. Secara tidak langsung spiritualitas Islam 
muncul sejak pada abad ke-7 M diawali dari pencerahan Nabi Muhammad saw kepada seluruh pengikutnya. Beliau memberikan pencerahan itu mengenai nilai-nilai moral dan spiritual yang telah diperoleh dari Allah SWT. Apa yang telah ditanamkan oleh Nabi saw kepada para pengikutnya yang awal, dalam tingkatan-tingkatan yang berbeda, adalah perasaan yang mendalam pada pertanggungjawaban di hadapan pengadilan Tuhan, yang mengangkat perilaku mereka dari alam duniawi dan kepatuhan yang mekanis kepada hukum, kepada alam kegiatan moral. Nilai-nilai moral dan spiritual yang telah diajarkan Nabi ternyata dapat memberikan perubahan bagi umat manusia hususnya Islam dalam mencapai derajat tertinggi (kehidupan hakiki). Pengalaman-Pengalaman spiritual tersebut dapat memberikan posisi kehidupan yang lebih baik dan dapat dirasakan dan dinikmati umat muslim (Islam).

Akhirnya apa yang telah dibawa Nabi saw itu dijadikan sebagai "sendi" dalam Islam guna mencapai kedekatan diri kepada Allah SWT. Lima sendi itu yang sering kita kenal dengan sebutan "Rukun Islam" dan kelima hal itu tetap berguna selama seseorang ingat bahwa dasar-dasar tersebut merupakan bagian kepercayaan dan bukan hanya suatu ibadah singkat yang diangkat. Lima sendi rukun Islam tersebut adalah: Pertama, Percaya bahwa tiada Tuhan selain Allah SWT dan Muhammad adalah utusan Allah SWT. Kedua, Shalat wajib lima kali dalam sehari semalam. Ketiga, Membayar Zakat kepada yang berhak menerimanya. Keempat, Puasa dari matahari terbit hingga terbenam selama tiga puluh hari pada bulan kesembilan, "Ramadhan" dan Kelima, Ibadah Haji ke Makkah sekali seumur hidup jika mampu secara materi dan sehat jasmani.

Dari lima sendi itulah yang akan membawa manusia pada tingkatan tertinggi dari agama Islam ketika manusia itu mau melaksanakan dan mencari titik temu dalam segi keagamaan. Karena dalam ajaran Islam tingkatan teritinggi terletak pada tingkat kesalehan manusia. Dimana kunci dari kesalehan ini adalah "takut kepada Tuhan" atau tanggung jawab kepada cita moral, atau yang sering disebut dengan istilah "taqwa".

Konsep al-Qur'an tentang berserah diri kepada Tuhan (taqwa), sebagaimana telah ditekankan oleh paham kesalehan dalam arti etisnya berkembang dalam kelompokkelompok tertentu menjadi suatu doktrin ekstrim tentang pengingkaran dunia. Maka dalam perilaku atau motivasi dari seseorang harus berlandaskan kesucian. Begitupun dalam semua aktifitas kegiatan manusia, hendaklah harus memiliki kesadaran akan pengawasan Tuhan. Taqwa merupakan salah satu kata yang paling tinggi nilainya, yang memiliki arti kurang lebih 'kemuliaan' dan 'kedermawanan'. Hingga pada akhirnya yang 
akan membawa manusia pada tingkat esoterisme atau yang tidak lain disebut dengan tingkat "spiritualitas". Spiritualitas Islam itu senantiasa identik dengan upaya menyaksikan yang satu, mengungkap yang satu, dan mengenali yang satu, sang tunggal itu yang ditegaskan dalam alQur'an adalah dengan nama "Allah SWT".

Oleh karena itu, seseorang ketika ingin mencapai tingkatan spiritualitas harus membersihkan hijab-hijab yang telah menghalangi penyatuan diri manusia dengan Tuhannya. Dalam bahasa tasawuf untuk mencapai tingkat spiritual ada tiga tahapan yang perlu diperhatikan, yakni Petama, mengosongkan dan membersihkan diri dari sifat-sifat keduniawiaan yang tercela (takhalli). Kedua, upaya mengisi atau menghasi dengan jalan membiasakan diri dengan sikap, perilaku, dan akhlak terpuji (tahalli). Ketiga, lenyapnya sifat-sifat kemanusiaan yang digantikan dengan sifat-sifat ketuhanan (tajalli). Dalam tradisi tasawuf, banyak sekali teori yang menyebut karakter keluhuran yang seharusnya dimiliki oleh manusia.

Spiritualitas dalam pandangan barat tidak selalu berkaitan dengan penghayatan agama bahkan Tuhan. Spiritualitas yang ada dalam pandangan mereka lebih mengarah pada bentuk pengalaman psikis yang pada ahirnya dapat memberi makna yang mendalam pada individu tersebut. Sebaliknya dalam pandangan orang-orang timur spiritualitas lebih mengarah dan terkait pada penghayatan religiusitas terhadap Tuhan dengan berbagai ajaran dan aturan didalamnya. Pada pandangan barat dan timur tentang spiritualitas pada lahirnya dapat mendasari penilaian dan perlakuan terhadap seni khususnya musik. Dalam psikologi barat, dikatakan bahwasanya puncak kesadaran manusia seutuhnya ditekankan terhadap tingkat rasionalitasnya, sedangkan dalam ranah kesufian orang-orang timur tidaklah begitu, kesadaran yang hanya diukur dari aspek rasionalitas seperti halnya "tidur dalam sadar", dikarenakan sisi spiritualitas dalam pendekatan diri terhadap tuhan tak pernah bisa terukur dengan hanya menggunakan ukuran rasionalitas. Beberapa contoh spiritualitas barat yang merefleksikan kesulitan orang barat dalam hal emosional dan seksualitas adalah aktris ternama Madona yang menjadi ikon seksualitas musik pop didunia barat, ekspresi yang digelar menyerukan kebutuhan untuk menjalani hidup secara langsung dan intens. Hal tersebut sekaligus mencerminkan kurangnya suatu autentisitas, terlebih lagi autentisitas terhadap pemaknaan musik dan fungsinya. Hal tersebut menggambarkan kepada kita bahwa musik yang dikonsumsi oleh barat secara fungsional hanya 
mengarah pada sebuah kepuasan yang tidak lebih dari ranah fenomena psikis yaitu seksualitas dan emosional

Orang yang mempunyai kecerdasaan spiritual, ketika menghadapi persoalan dalam hidupnya, tidak hanya dihadapi dan dipecahkan dengan rasional dan emosional saja, tetapi ia menghubungkannya dengan makna kehidupan secara Spiritual. Dengan demikian, langkah-langkahnya lebih matang dan bermakna dalam kehidupan.

Menurut Danah Zohar dan Ian Marshal (dalam Azzet, 2013) ada beberapa tanda orang yang mempunyai kecerdasaan spiritual yaitu, ditandai dengan sikap hidupnya yang fleksibel atau bisa luwes dalam menghadapi persoalan. Fleksibel disini bukan berarti munafik atau bermuka dua. Fleksibel bukan berarti tidak mempunyai pendirian.akan tetapi Fleksibel karena memiliki pengetahuan yang luas.

Orang yang fleksibel akan mudah menyesuaikan diri dalam berbagai situasi dan kondisi. Orang yang fleksibel juga tidak akan memaksakan kehendak dan tak jarang mudah mengalah dengan orang lain. Meskipun demikian, ia lebih mudah menerima kenyataan dengan hati yang lapang.

Orang yang memiliki tingkat kesadaran yang tinggi berarti ia mengenal dengan baik siapa dirinya. Orang demikian lebih baik dalam mengendalikan dirinya dalam berbagai situasi dan keadaan, termasuk dalam mengendalikan emosi. Dengan mengenal diri secara baik seseorang akan lebih mudah dalam memahami orang lain. Dalam kaitannya dengan tahap spiritual ia lebih mudah untuk mengenal Tuhannya.

Dalam menghadapi persoalan hidup yang semakin kompleks, tingkat kesadaran yang tinggi ini sangat penting sekali. Tidak mudah baginya untuk putus asa dan jauh dari kemarahan.

Tidak banyak orang yang dapat menghadapi penderitaan dengan sangat baik. Pada umumnya manusia jika dihadapkan dengan penderitaan, akan mengeluh, kesal, marah, atau bahkan putus asa, namun orang yang memiliki kecerdasan spiritual yang baik akan mempunyai kemampuan dalam menghadapi penderitaan dengan sangat baik. Kemampuan menghadapi penderitaan ini didapatkan karena seseorang mempunyai kesadaran bahwa penderitaan ini terjadi sesungguhnya untuk membangun dirinya supaya menjadi manusia yang lebih kuat.

Setiap orang pasti memiliki rasa takut, entah sedikit ataupun banyak. Takut terhadap apa saja, termasuk takut menhhadapi kehidupan. Dalam menghadapi rasa takut ini, tidak sedikit manusia yang di jangkiti oleh rasa khawatir yang berlebihan, 
bahkan berkepanjangan. Padahal apa yang ditakutkan itu, belum tentu terjadi. Takut menghadapi kemiskinan, misalnya bisa berlebihan, rasa takut itu bisa membuat seseorang lupa terhadap hukum dan nilai. Akhirnya, dalam rangka supaya hidupnnya tidak miskin, ia tidak segan untuk menipu, berbohong, mencuri, atau melakukan korupsi.

Tidak demikian untuk orang yang memiliki kecerdasaan spiritual yang tinggi. Ia mampu menghadapi dan mengelola rasa takut itu dengan sangat baik. Dengan sabar ia akan menghadapi segala sesuatu. Kesabaran dalam banyak hal memang bisa bermakna sebagai keberanian seseorang dalam menghadapi kehidupan. Hal ini bisa terjadi karena orang yang memiliki kecerdasaan spiritual juga mempunyai kesadaran yang kuat dalam keyakinan jiwanya

Tanda lain orang yang memiliki kecerdasan spiritual adalah hidupnya berkualitas karena diilhami oleh visi dan nilai. Visi dan nilai inilah yang sangat bermakna dalam kehidupnnya. Tidak jarang orang yang mudah terpengaruh oleh bujuk rayu karena memang tidak memiliki visi dan nilai. Atau mempunyai Visi dan nilai, namun tidak memiliki peggangan yang kuat.

Visi dan nilai dari seseorang bisa jadi disandarkan kepada keyakinan kepada Tuhan, atau bisa juga berangkat dari visi dan nilai yang diyakininya berangkat dari pengalaman hidup. Visi dan nilai yang dimiliki oleh seseorang bisa membuat hidupnya terararh tidk goyah ketika menghadapi cobaan, dan lebih mudah dalam menghadapi cobaan.

Orang yang mempunyai kecerdasaan spiritual yang baik akan enggan bila keputusan atau langkah-langkah yang diambilnya bisa menyebabkan kerugian yang tidak perlu. Hal ini bisa terjadi karena ia berpikir lebih selektif dalam mempertimbangkan berbagai hal.

Berpikir selektif dan menghasilkan langkah yang efektif sebagaimana tersebut penting sekali dalam kehidupan. Disamping bisa menghemat banyak hal, langkah yang demikian akan disukai oleh banyak orang karena karena tidak membuat orang dalam kerugian. Ini hasil kecerdasan spiritual yang baik karena seseorang mempertimbangkannya dengan kekayaan jiwa.

Agar keputusan dan langkah yang diambil oleh seseorang dapat mendekati keberhasilan, diperlukan kemampuan dalam melihat keterkaitan antara berbagai hal. 
Agar hal yang dipertimbangkan itu menghasilkan kebaikan, sangat perlu melihat keterkaitan antara berbagai hal dalam sebuah masalah. Inilah cara pandang holistic.

Akan tetapi, tidak semua orang mempunyai kecenderungan untuk melihat keterkaitan berbagai hal dari sebuah kejadian yang sedang dihadapinya. Hanya orang orang yang mempunyai kecerdasan Spiritual yang mampu melakukannya. Dengan demikian, orang tersebut akan tampak lebih matang dan berkualitas di berbagai hal dalam kehidupannya

Pertanyaan “ Mengapa” dan "Bagaimana” jika biasanya dilakukan oleh seseorang untuk mencari jawaban yang mendasar. Inilah tanda bagi orang yang mempunyai kecerdasaan spiritual yang tinggi. Dengan demikian, ia dapat memahami masalah dengan baik, tidak secara parsial, dan dapat mengambil keputusan secara baik pula.

Pertanyaan "mengapa" dan "Bagaimana" jika itu penting sekali agar seseorang tidak terjebak dalam suatu masalah. Hal ini juga penting agar seseorang mempunyai banyak kemungkinan sebagai jalan keluar dalam menghadapi suatu masalah. Sungguh ini penting agar seseorang bisa merencanakan tujuan dengan baik demi mencapai sebuah keberhasilan.

Orang yang memiliki kecerdasaan spiritual yang tinggi akan bisa menjadi pemimpin yang penuh pengabdian dan bertanggung jawab. Lebih dari itu, kenyataan ini adalah tantangan sekaligus tanggung jawab yang mulia dari orang tua agar bisa mengembangkan kecerdasaan spiritual pada anaknnya.

Resimen Mahasiswa (Menwa) merupakan suatu sarana pengembangan diri mahasiswa ke arah perluasan wawasan dan peningkatan keikutsertaan dalam upaya bela negara dan penguatan ketahanan nasional. Sebagai perorangan, merupakan mahasiswa terlatih olah keprajuritan yang telah mengikuti latihan dasar Resimen Mahasiswa Indonesia dan menjadi bagian dari komponen pertahanan negara. Sebagai organisasi merupakan pusat aktifitas anggota Resimen Mahasiswa Indonesia yang terdiri dari tingkat Nasional, tingkat provinsi dan tingkat kabupaten/kota serta di Perguruan tinggi.

Tujuan didirikannya Menwa adalah untuk mempersiapkan mahasiswa yang memiliki pengetahuan, sikap disiplin, fisik dan mental serta berwawasan kebangsaan agar mampu melaksanakan tugas Tri Dharma Perguruan Tinggi dan menanamkan dasar-dasar kepemimpinan dengan tetap mengacu pada tujuan pendidikan nasional. Selain itu, didirikannya organisasi Menwa adalah sebagai wadah penyaluran potensi 
mahasiswa dalam rangka mewujudkan hak dan kewajiban warga Negara dalam Bela Negara dan mempersiapkan potensi mahasiswa sebagai bagian dari potensi rakyat dalam Sistem Pertahanan Rakyat Semesta (SISHANRATA).

Tugas pokok Resimen Mahasiswa meliputi pelaksanakan Tri Dharma Perguruan Tinggi serta membantu terlaksananya kegiatan dan program lainnya di Perguruan Tinggi, merencanakan, mempersiapkan dan menyusun seluruh potensi mahasiswa untuk memantapkan ketahanan nasional, dengan melaksanakan usaha dan atau kegiatan bela negara, membantu terwujudnya penyelenggaraan fungsi perlindungan masyarakat (LINMAS), khususnya Penanggulangan Bencana dan Pengungsi (PBP),dan membantu terlaksananya kesadaran bela negara dan wawasan kebangsaan dalam organisasi kepemudaan.

Resimen Mahasiswa Indonesia mempunyai fungsi melaksanakan pembinaan anggota Resimen Mahasiswa Indonesia di Perguruan Tinggi untuk meningkatkan kemampuan dalam bidang akademik, melaksanakan pemeliharaan dan pemberdayaan serta peningkatan kemampuan baik perorangan maupun satuan di bidang Bela Negara, melaksanakan pembinaan disiplin anggota Resimen Mahasiswa Indonesia, baik sebagai mahasiswa maupun warga masyarakat, melaksanakan pembinaan struktur organisasi Resimen Mahasiswa Indonesia sebagai satu kesatuan yang utuh, bersama dengan mahasiswa lainnya membantu terwujudnya kehidupan kampus yang kondusif, membantu kelancaran pelaksanaan kegiatan dan program civitas akademika serta menumbuhkan dan meningkatkan sikap Bela Negara dikehidupan Perguruan Tinggi, membantu memotivasi masyarakat untuk ikut berpartisipasi secara aktif dalam pembangunan nasional dibidang kepemudaan dalam upaya penanggulangan penyalahgunaan narkoba di kalangan generasi muda dan membantu TNI/POLRI dalam pelaksanaan pembinaan pertahanan dan keamanan Nasional.

Untuk mencapai berbagai tujuan, memenuhi fungsi dan tugas pokok sebagai anggota Resimen Mahasiswa ternyata tidak hanya dibutuhkan kekuatan fisik dan mental saja. Namun juga dibutuhkan penguatan spiritual agar anggota menwa memperoleh makna positif dari berbagai kegiatan yang dilakukannya. Tolok ukur spiritualitas yang dimaksud dalam tulisan ini adalah berdasarkan apakah seorang anggota Menwa memiliki kecerdasan spiritual dalam melaksanakan tugasnya. Apakah ia memiliki kemampuan bersikap fleksibel, memiliki tingkat kesadaran yang tinggi atau kemampuan mengelola emosi jika menghadapi persoalan, mampu menghadapi 
penderitaan dari latihan-latihan fisik dan mental yang cukup berat dan tidak dihadapi oleh mahasiswa lain seusianya, mampu menghadapi rasa takut, memiliki kualitas hidup yang diilhami oleh visi dan nilai serta memiliki rasa humor

Penguatan spiritualitas yang dimaksud adalah apakah keluarga dan lingkungan mendukung terbentuknya kecerdasan spiritual tersebut jika anaknya menjadi anggota Resimen Mahasiswa. Hal-hal tersebut yang akan menjadi pokok bahasan dalam tulisan ini.

\section{Metode Penelitian}

Penelitian ini merupakan penelitian dengan metode penelitian kualitatif. Teknik sampling yang digunakan adalah purposive sampling. Empat partisipan dilibatkan dalam penelitian ini. Semua subjek penelitian tersebut adalah anggota Resimen Mahasiswa Universitas X. Pengumpulan data dilakukan dengan metode wawancara dan observasi. Teknik yang digunakan dalam peengolahan data hasil penelitian adalah teknik triangulasi data.

\section{Hasil Penelitian}

Hasil observasi dan wawancara dari menwa universitas X, mereka selalu menjawab pertanyaan selalu didahului dengan kata-kata SIAP. Jika ada waktu perkuliahan yang berdekatan dengan waktu tugas, mereka tetap menggunakan baju seragam ketika mengikuti kuliah. Untuk mengatakan tentang pendapatnya, anggota menwa menggunakan kata-kata MOHON IJIN.

Hasil observasi dan wawancara juga menunjukkan bahwa anggota Menwa memiliki kemampuan berpikir fleksibel, tingkat kesadaran yang tinggi dalam mengelola emosi, mampu menghahadapi penderitaan dan rasa takut, memiliki visi dan nilai dalam melaksanakan kegiatan serta sesekali tetap diselingi dengan rasa humor.

Hasil penelitian tersebut menggambarkan adanya penguatan spiritualitas yang dibangun di dalam komunitas Resimen Mahasiswa melalui berbagai kegiatan yang dilaksanakannya.

\section{Diskusi}

Spiritualitas merupakan suatu kemampuan untuk memahami makna dari suatu kegiatan yang dilakukan dalam suatu perjalanan hidup. Makna hidup yang ingin 
diperoleh seorang individu tidak bisa didapat jika hanya berdiam diri saja. Ada berbagai peristiwa yang perlu dihadapi seseorang untuk memperoleh penguatan spiritual.

Menurut Azzet (2013) ada beberapa cara untuk mengembangkan penguatan spiritual. Cara yang bisa dilakukan antara lain adalah membiasakan diri berpikir positif, memberikan sesuatu yang terbaik dan menggali hikmah di setiap kejadian.

Latihan penting yang perlu dilakukan menurutnya adalah dengan jalan senang berbuat baik, senang menolong orang lain, turut merasa memikul sebuah misi mulia dan mempunyai selera humor yang baik dan senang mengunjungi orang yang mengalami kesusahan.

Penguatan spiritualitas mendorong individu untuk memaknai nilai-nilai kehidupan, berkomitmen dan bertanggung jawab (Hudha, 2012). Namun hal tersebut, memerlukan media yang dapat menstimulasi individu menemui maknanya dalam suatu kegiatan. Resimen Mahasiswa memfasilitasi adanya berbagai kegiatan yang dapat dijadikan media untuk memperoleh penguatan dan mengasah kecerdasan spiritual.

Kemampuan berfikir fleksibel, mengelola emosi dengan penuh kesadaran, kemmpuan menghadapi penderitan, mengatasi rasa takut, memiliki visi dan nilai dalam menjalankan tugas dan tetap memiliki rasa humor adalah nilai-nilai spiritual yang diperoleh anggota menwa di komunitasnya.

Hal-hal yang perlu didiskusikan adalah bagaimana penguatan spiritual di menwa bisa dipertahankan dan bisa dikembangkan agar bermanfaat bagi seluruh anggota menwa pada khususnya dan generasi muda Indonesia pada umumnya.

\section{Simpulan}

Penguatan spiritualitas dalam komunitas Resimen Mahasiswa diperoleh dari berbagai kegiatan yang dijalani oleh para anggotanya yang mau menjalani segala sesuatunya dan mampu mengambil makna dari kejadian yang disukai maupun yang tidak disukainya.

Penguatan untuk memperoleh spiritualitas yang baik perlu dilakukan dengan memahami persoalan-persoalan yang harus dihadapi dan dipecahkan bersama dalam komunitas Menwa.

Masih banyak hal yang harus dilakukan untuk memberi penguatan pada seluruh anggota Menwa agar setiap anggota mampu memperoleh makna dari setiap tugas dan kegiattan yang dilakukannya. Diharapkan upaya penguatan spiritualitas di Menwa juga 
dapat dikembangkan di organisasi kemahasiswaan yang lain agar generasi muda tidak hanya cerdas secara akademik saja namun juga cerdas secara emosional dan spiritual.

\section{Daftar Pustaka}

Anwar, R dan Solihin, M. (2000) Ilmu Tasawuf. Bandung : Pustaka Setia

Azzet, A.M. (2013). Mengembangkan kecerdasan spiritual bagi anak. Yogyakarta: Kata Hati

Diener, E. (2008) Happiness. Unlocking the Mysteries of Psychological Wealth. USA: Amazon Books

Frager,R. (2014) Psikologi Sufi, trasformasi hati, jiwa dan ruh. Jakarta: Zaman

Hudha, A.M. (2012) Menjadi pribadi inovatif, kreatif, mandiri yang berspiritualitas. Malang: AM Publishing

M.W. Shafwan, (2000) Wacana Spiritual Timur dan Barat, Yogyakarta : Qalam

Nasution, A.T.(2009). Melejitkan SQ dengan prinsip 99 asmaul husna merengkuh puncak kebahagiaan dan kesuksesan hidup

Suseno, M.N. (2012) Motivasi spiritual dan komitmen afektif pada karyawan. Jurnal Psikologi. Diri dan Spiritualitas. Universitas Islam Negeri Sunan Kalijaga Yogyakarta,Volume V Nomor 1, hal 31-43 